\title{
IMPLEMENTASI CYBER PUBLIC RELATIONS UNIVERSITAS SINGAPERBANGSA KARAWANG PADA PERSAINGAN ERA DIGITAL
}

\author{
Tri Susanto', Wahyu Utamidewi ${ }^{2}$, Reka Prakarsa Nur Muhamad ${ }^{3}$, Satria Ali Syamsuri ${ }^{4}$ \\ ${ }^{1}$ Program Studi Ilmu Komunikasi, Universitas Singaperbangsa Karawang \\ Email : Tri.susanto@staff.unsika.ac.id \\ ${ }^{2}$ Program Studi Ilmu Komunikasi, Universitas Singaperbangsa Karawang \\ Email : wahyu.utamidewi@fisip.unsika.ac.id \\ ${ }^{3}$ Program Studi Ilmu Komunikasi, Universitas Singaperbangsa Karawang \\ Email : prakarsa.reka@gmail.com \\ ${ }^{4}$ Program Studi Ilmu Komunikasi, Universitas Singaperbangsa Karawang \\ Email : sasyamsuri@gmail.com
}

Masuk :12-04-2019, revisi: 15-09-2019, diterima untuk diterbitkan : 16-09-2019

\begin{abstract}
ABSTRAK
Penggunaan teknologi dalam kegiatan public relations sangat dibutuhkan dalam membangun network kepada baik konsumen ataupun relations yang dibutuhkan dalam sebuah institusi/perusahaan, dalam hal ini dikenal dengan istilah cyber Public Relations, yaitu suatu usaha seorang public relations yang menggunakan media internet sebagai sarana publikasinya dalam meningkatkan reputasi baik tingkat nasional maupun internasional. Persaingan yang ketat pada era digital menuntut perguruan tinggi terus bersaing dalam pemenuhan informasi pada khalayak, dalam proses ini Humas Unsika merupakan bagian terpenting dalam kegiatan cyber public relations. Penelitian ini dilakukan dengan metode penelitian kualitatif dengan sifat deskriptif. Dengan tujuan penelitian untuk mengetahui dan menganalisis serta mengevaluasi kegiatan cyber public relations yang telah dilakukan oleh Universitas Singaperbangsa Karawang selama ini semenjak beralih status dari swasta menjadi Negeri. Dalam hal ini kegiatan cyber public relations terkait dengan publikasi online berupa press release, kerjasama, jurnal online, siakad, video maupun penyedia informasi pada situs resmi Universitas Singaperbangsa Karawang. Selain itu faktor pendukung lainnya adalah penggunaan media sosial karena kekuatan media sosial dalam menggalang opini di dunia maya mulai diperhitungkan banyak pihak, tidak mengherankan jika suatu merek institusi dapat dicitrakan secara baik tetapi juga dihancurkan melalui penggalangan opini melalui media sosial. Tetapi, kurang maksimalnya aktifitas cyber PR Unsika membuat Institusi ini cukup sulit bersaing di media internet. Peneliti berharap dengan adanya penelitian ini menjadi tinjauan serta masukan agar humas dapat meningkatkan aktivitas cyber public relations di Universitas Singaperbangsa Karawang dengan baik ke depannya sehingga dapat bersaing dalam tingkat nasional maupun internasional.
\end{abstract}

Kata Kunci: Cyber PR, Media Sosial, Universitas Singaperbangsa Karawang.

\section{ABSTRACT}

The use of technology in public relations is needed for building networks toward consumers or important relations in an institution / company, in this case known as cyber Public Relations, an effort by public relations to utilize internet media as a mean of publicity in improving good reputation both nationally and internationally. Intense competition in the digital era requires universities to compete in sharing information to the public. In this process the Unsika Public Relations is the most important part in cyber public relations. This research was conducted using qualitative research method with descriptive nature. The aim of this research is to find out, analyze, and evaluate cyber public relations activities carried out by the University of Singaperbangsa Karawang so far after having its status changed from a private university to public university. In this case, cyber public relations activities related to online publications are in the form of press releases, cooperation, online journals, news, videos, and information provision on the official site of the University of Singaperbangsa Karawang. Meanwhile, another supporting factor is the use of social media for its capability to rally a certain opinion has begun to be taken into account by many parties. It is not surprising that an institutional brand can either be well-perceived, or ill-perceived through the gathering of opinions on social media. However, the lack of Unsika cyber PR activities hinders this university from competing on the internet media. The researchers hope that this research serves as a review and a suggestion for public relations to increase cyber public relations activities at the University of Singaperbangsa Karawang in the future to allow it to compete on national and international levels.

Keywords: Cyber PR, Social Media, University Singaperbangsa Karawang. 


\section{PENDAHULUAN}

\section{Latar Belakang}

Perkembangan teknologi dan komunikasi mengubah perilaku masyarakat dalam memperoleh informasi baik melalui televisi, radio, telepon bahkan faxmail sudah menjadi hal yang biasa dikalangan masyarakat. Salah satu hasil teknologi dan komunikasi atau pun informasi yang luar biasa saat ini adalah internet. Internet telah membuat dunia tak lagi berjarak, kehadirannya mengubah cara konsumen atau pelanggan memanfaatkan media. Kondisi ini membuka pemahaman baru bagi kalangan bisnis dan praktisi Public Relations (PR) untuk menemukan kembali cara mengelola dan memelihara reputasi melalui pendekatan yang dinamakan sebagai Cyber Public Relations. Dengan adanya teknologi internet, maka menghadirkan media dengan platform lain yaitu media online, karena itu para praktisi $P R$ dihadapkan dengan tantangan bagaimana memanfaatkan media interaktif ini.

Cyber Public Relations adalah salah satu kegiatan seorang $P R$ (public relations) yang menggunakan Cyber World (dunia maya) dalam menjalin kerjasamanya. Penggunaan internet oleh para profesional merupakan cikal bakal dari perkembangan internet yang semakin pesat. Pemakaian internet sangatlah efektif, terutama pada krisis komunikasi, mengidentifikasi masalah, manajemen dan komunikasi interaktif. Saat ini Cyber Public Relations menuju zaman keemasan dimana masyarakat sekarang beralih kemedia yang dianggap praktis ini, penggunaan internet saat ini dikalangan masyarakat sangatlah membantu seorang $P R$ dalam melaksanakan kegiatannya yaitu membangun citra perusahaan yang dikelolanya.

Penggunaan teknologi dalam kegiatan $P R$ sangat dibutuhkan dalam membangun network kepada semuanya baik konsumen ataupun relations yang dibutuhkan dalam sebuah perusahaan. Untuk itu penggunaan media sosial sangat dibutuhkan dimana pada zaman sekarang ini generasi muda lebih menyukai dunia maya. Dengan adanya teknologi seperti ini maka seorang $P R$ hendaknya mengetahui tentang media sosial yang sedang marak digunakan pada saat ini. Media sosial merupakan situs dimana setiap orang bisa membuat web page pribadi, kemudian terhubung dengan teman-teman untuk berbagi informasi dan berkomunikasi. Media sosial terbesar antara lain facebook, myspace, twitter. Jika media tradisional menggunakan media cetak dan media broadcast, maka media sosial menggunakan internet. Media sosial mengajak siapa saja yang tertarik untuk berpartisipasi dengan mengajak siapa saja yang tertarik untuk berpartisipasi dengan memberikan kontribusi dan feedback secara terbuka, memberi komentar serta membagi informasi dalam waktu capat dan tak terbatas.

Model Komunikasi ini menciptakan komunitas dengan cepat karena adanya ketertarikan yang sama terhadap suatu hal. Perkembangan ini tentu saja sangat pantas diperhatikan mengingat fungsi dan peran media sosial dalam berbagai hal terasa sangat signifikan. Pada dasarnya komunikasi yang dianggap paling efektif adalah jenis komunikasi yang dilakukan dari mulut ke mulut (word of mouth). Dengan bantuan teknologi media sosial, jaringan informasi dari mulut ke mulut tidak harus lagi dilakukan secara tatap muka. Facebook, twitter dan berbagai media sosial lainnya adalah sarana yang dapat kita gunakan, untuk berkomunikasi dari mulut ke mulut dengan lebih cepat dan lebih luas lingkup penyebarannya.

Kekuatan media sosial dalam menggalang opini di dunia maya mulai diperhitungkan banyak pihak, tidak mengherankan jika suatu merek perusahaan dapat dicitrakan secara baik tetapi juga dihancurkan melalui penggalangan opini melalui media sosial. Untuk itu sangat penting sekali perusahaan dapat memahami dan memberikan penjelasan agar pengguna media sosial mengerti akan citra perusahaan yang akan dibangun melalui media sosial. Penggunaan media sosial sangat bermanfaat sekali dalam pembangunan citra perusahaan, dan juga bisa menjadi ancaman jika tidak bisa di manajemen secara baik. 
Salah satu perguruan tinggi negeri yang berada di Jawa Barat adalah Universitas Singaperbangsa Karawang, Universitas ini merupakan alih bentuk dari swasta menjadi negeri sejak 6 Oktober 2014, status Univeritas Singaperbangsa Karawang berubah menjadi Perguruan Tinggi Negeri (PTN) berdasarkan Peraturan Presiden RI (Perpres) No. 123 Tahun 2014. Peluang dalam meningkatkan citra institusi pada era digital sangat besar sehingga dibutuhkan manajemen Public Relations yang profesional kegiatan itu merupakan cyber public relations. Data awal menunjukan Universitas Singaperbangsa Karawang masih butuh perbaikan dalam cyber public relations. Peneliti mencoba membandingkan 5 (lima) perguruan tinggi yang berada di wilayah jawa barat melalui similarweb.com yaitu: 1) Universitas Padjadjaran 2) Institut Pertanian Bogor 3) Universitas Siliwangi. 4) Universitas Singaperbangsa Karawang (UNSIKA) 5) Universitas Buana Perjuangan (UBP) Karawang pasca alih status UNSIKA menjadi Perguruan Tinggi Negeri (PTN). Dari lima perguruan tinggi peneliti berinisiatif untuk membandingkan website dengan hasil seperti dibawah ini.
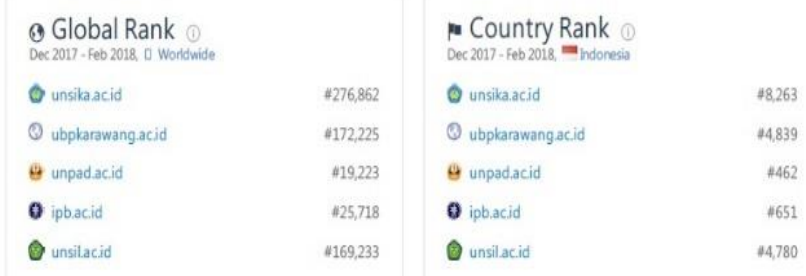

Gambar 1. Global Rank

Sumber gambar : similarweb.com

Pada gambar 1 diatas memperlihatkan bahwa peringkat dunia dari lima perguruan tinggi tersebut menunjukan bahwa website unsika.ac.id pada posisi 276,862 berada dibawah ubpkarawang.ac.id yang merupakan perguruan tinggi swasta di kota karawang pecahan dari Unsika sendiri. Sedangkan website Unsil.ac.id berada pada posisi ke 3 padahal status universitas ini sama dengan Unsika yaitu perguruan tinggi negeri baru namun posisi global rank nya sangat jauh sekali dan hasil yang sama ditunjukan pada country rank.

Sedangkan dari data visitor periode Desember 2017 - Februari 2018 Unsika berada diatas UBP Karawang dengan jarak yang tidak terlalu jauh. Sehingga jika Unsika tidak memperbaiki manajemen sistem informasi akan dikhawatirkan berada di posisi akhir.

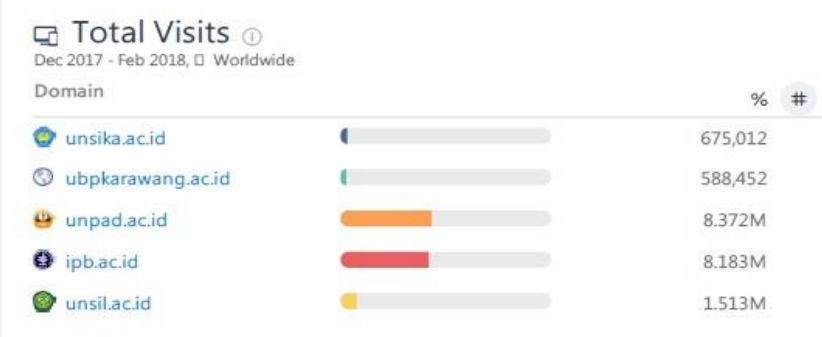

Gambar 2. Total Visitor periode Desember 2017 - Februari 2018

Sumber gambar : Similarweb.com 
Selain melalui website Unsika seharusnya juga memiliki manajemen pengelolaan media sosial yang baik, data awal menunjukan media sosial yang digunakan belum maksimal. Selain website media cyber $P R$ lainnya yang dipakai Unsika adalah facebook dengan follower dan like sebanyak 2.173 dan 2.140 selain itu akun ini terakhir aktif pada tanggal 23 Desember 2017. Pada akun ini tidak ditemukan adanya komunikasi yang efektif, walaupun memiliki follower dan like namun tidak ada informasi yang dapat dibaca mengenai civitas akademika Unsika. Media sosial lainnya yaitu twitter Unsika yaitu akun @Unsikainfo namun akun tersebut tidak memiliki cuitan satupun. Selanjutnya media sosial instagram unsika memiliki akun official namun tidak update serta caption yang tidak komunikatif follower-nya baru 331 padahal mahasiswa UNSIKA banyak menggunakan media sosial instagram. Sedangkan media sosial youtube akun official unsika hanya digunakan untuk tutorial sistem akademik online saja, sehingga tidak ada konten yang menarik dalam penggunaan youtube.

\section{Rumusan Masalah}

Dari pembahasan diatas, peneliti tertarik untuk mengetahui beberapa masalah dalam penelitian ini, yaitu: 1) Bagaimana aktivitas cyber public relations yang telah diterapkan Universitas Singaperbangsa Karawang?; 2) Apa saja kendala yang membuat terhambatnya proses cyber public relations dalam meningkatkan citra positif institusi pada era digital dan 3) Bagaimana strategi public relations menghadapi tantangan dalam persaingan cyber public relations?

\section{METODE PENELITIAN}

Penelitian ini menggunakan studi deskriptif yang merupakan tipe metode penelitian kualitatif (Qualitatif Research), studi deskriptif merupakan pemaparan suatu situasi atau peristiwa (Ruslan, 2006:71-72). Disini, penelitian deskriptif hanyalah memaparkan situasi atau peristiwa. Penelitian tidak mencari dan menjelaskan hubungan, tidak menguji hipotesis (Rakhmat, 2008:24). Subyek penelitian adalah bagian PR/Humas Universitas Singaperbangsa Karawang sebagai pengelola website dan media sosial yang digunakan. Cara pengambilan sampel menggunakan teknik adalah purposive sampling yaitu setiap elemen dalam populasi tidak memiliki kesempatan yang sama untuk dipilih menjadi sampel. Metode purposive sampling digunakan karena elemen-elemen yang dipilih menjadi unit sampel dianggap dapat memberikan informasi yang dibutuhkan oleh peneliti (Widodo, 2004:48). Dalam penelitian ini, peneliti melakukan wawancara kepada bagian PR/Humas Universitas Singaperbangsa Karawang. Penelitian ini mengambil website dan media sosial yang digunakan Universitas Singaperbangsa Karawang sebagai Obyek.

Jenis data yang diperoleh dibagi 2 (dua) yaitu data primer dan data sekunder. Data primer didapat melalui wawancara sedangkan data sekunder dalam penelitian ini adalah observasi dan studi pustaka. Dalam penelitian ini menggunakan teknik pengumpulan data berupa wawancara, observasi dan studi pustaka. Metode yang digunakan dalam pemeriksaan keabsahan data dalam penelitian ini adalah Triangulasi. Triangulasi ialah kombinasi beragam sumber data, tenaga peneliti, teori dan teknik metodologis dalam suatu penelitian atas gejala sosial. Triangulasi diperlukan karena setiap teknik memiliki keunggulan dan kelemahannya sendiri. Dengan demikian triangulasi memungkinkan tangkapan realitas secara lebih valid (Pawito, 2007:97). Dalam penelitian ini peneliti menggunakan teknik triangulasi data yaitu upaya peneliti untuk mengakses sumber-sumber yang lebih bervariasi guna memperoleh data berkenaan dengan persoalan yang sama. Dimana peneliti mencocokan data yang telah diperoleh melalui wawancara, observasi dan juga studi pustaka. 


\section{HASIL DAN PEMBAHASAN}

\section{Aktivitas Cyber Public Relations Universitas Singaperbangsa Karawang}

\section{Media Cyber PR Universitas Singaperbangsa Karawang}

Media sosial adalah istilah untuk situs jejaring sosial yang menggunakan media baru, misalnya internet, website, media sosial misalnya, facebook, twitter, Instagram dan youtube sebagainya. Tujuan sosial media bagi kegiatan $P R$ antara lain adalah: 1) Mampu meningkatkan hubungan antara perusahaan dengan konsumen. Sosial media mampu merubah gaya komunikasi menjadi lebih interaktif dan partisipatif, hal ini menyebabkan hubungan antara perusahaan dengan konsumennya menjadi lebih intens, lebih personal dan setara (horisontal). Media sosial memungkinkan konsumen untuk berkomentar langsung dengan apa yang sedang dilakukan atau yang sedang terjadi dengan perusahaan tersebut; 2) Mampu mempercepat proses pembuatan keputusan. Dengan melemparkan sebuah topik atau survey akan sesuatu, maka konsumen dapat memberikan pendapatnya akan sesuatu tersebut dengan cepat, sehingga memudahkan untuk dapat membuat keputusan secara cepat; 3) Meningkatkan brand awareness dan user engagement. Dengan media sosial, maka sebuah brand mampu mengumpulkan komunitaskomunitasnya dalam satu wadah tertentu, hal ini tentu saja akan memudahkan brand untuk melakukan promosi atau sekedar untuk berinteraksi dengan konsumen. Sebagai konsumen pun merasa semakin dilibatkan dalam berbagai hal, karena suaranya semakin mudah terdengar; 4) Memudahkan marketing. Hal ini dapat diartikan bahwa sebuah ide dapat berkembang lebih cepat dengan melemparkan ide tersebut di media sosial; 5) Menurunkan biaya. Media sosial meningkatkan efisiensi dari perusahaan, antara lain mengurangi biaya komunikasi karena dengan media sosial setiap user adalah "juru bicara", dapat juga mengurangi biaya riset karena media sosial memudahkan untuk melakukan survey langsung kepada konsumen dan mendapatkan masukan langsung dari konsumen. Adanya media cyber memberikan sebuah channel baru bagi perusahaan untuk berinteraksi secara berbeda dengan konsumen. Jika mampu dimanfaatkan dan dikelola secara baik, maka dapat memberikan banyak dampak positif bagi perusahaan. Namun begitu pula sebaliknya, tanpa adanya tujuan, rencana dan rambu-rambu yang jelas, maka akan memberikan kerugian bagi perusahaan. Beberapa media cyber $P R$ yang digunakan Universitas Singaperbangsa Karawang

\section{a. Website}

Website atau situs dapat diartikan sebagai kumpulan halaman yang menampilkan informasi data teks, data gambar diam atau gerak, data animasi, suara, video dan atau gabungan dari semuanya, baik yang bersifat statis maupun dinamis yang membentuk satu rangkaian bangunan yang saling terkait dimana masing-masing dihubungkan dengan jaringan-jaringan halaman (hyperlink). Bersifat statis apabila isi informasi website tetap, jarang berubah, dan isi informasinya searah hanya dari pemilik website. Bersifat dinamis apabila isi informasi website selalu berubah-ubah, dan isi informasinya interaktif dua arah berasal dari pemilik serta pengguna website.

Website www.unsika.ac.id dapat dikategorikan website statis (static website) adalah sebuah website yang kontennya statis. Sekali dibuat dan online di Internet, pada umumnya website tersebut tidak dapat diubah kecuali diubah secara manual melalui pengubahan bahasa pemograman website tersebut. Oleh karena itu, terjadinya interaksi pun jarang sekali, sehingga dapat dikatakan seperti brosur online karena informasi yang diberikan juga terbatas.

Dalam kegiatan cyber $P R$ di website www.unsika.ac.id banyak kekurangan yang harus diperbaiki yaitu beberapa Halaman tidak bisa diakses digital library, beberapa website pendukung yaitu website fakultas tidak dapat diakses, bahkan ada yang masih menggunakan domain wordpress.com. Fakultas Ilmu Sosial dan Ilmu Politik memiliki alat website yaitu www.fisip.unsika.ac.id. Tampilan website milik Fisip Unsika ini standar dan masih harus mengalami peningkatan dan beberapa foto yang ditampilan sudah perlu di update. Link website 
fakultas tidak terdapat di website universitas. Informasi yang ditampilkan terakhir tahun 2017 tentang tracer. Beberapa kali website down dan diperlukan admin fakultas yang selalu memperbarui informasi. Fakultas Hukum dengan www.fh.unsika.ac.id. Tampilannnya statis dan Standar masih harus mengalami peningkatan dan beberapa foto yang ditampilan sudah perlu di update. Informasi yang ditampilkan terakhir tahun 2017 tentang pembimbing skripsi. Tidak memuat Prestasi dosen dan mahasiswa, agenda kegiatan. Fakultas Agama Islam dengan https://prodipaiunsika.wordpress.com/. Ketika menuju link FAI maka akan masuk ke prodi Pendidikan Agama Islam dan tidak menemukan website fakultas. Website PAI ini masih menggunakan wordpress sehingga seperti blog pribadi. Informasi tentangaktifitas, acara dan prestasi dosen ataupun mahasiswa tidak ditemukan yang ditampilkan berupa tulisan dakwah dari dosen. Fakultas ekonomi dan bisnis dengan website http://www.feunsika.ac.id/ dan tidak dapat diaksis. Fakultas keguruan dan Ilmu Pendidikan dengan http://fkip.unsika.ac.id/ index.php. Tampilan standar namun di website FKIP mahasiswa dan dosen dapat Log in untuk mengakses informasi yang dibutuhkan. Informasi yang ditampilkan berupa pengumuman infrormasi Beasiswa PPA dan info cukup update namun tidak juga menemukan kegiatan dosen, mahasiswa baik presetasi maupun aktifitas. Fakultas Pertanian dengan website http://faperta.unsika.ac.id/index.php?. Tampilan awal terlihat buah apel hijau segar. Saat pertama kali melihat website ini peneliti mengira masuk dalam website perkebunan apel. Dari menu publikasi yang ditampilkan semuanya tidak ada isi yang dapat dibaca. Fakultas Ilmu Kesehatan dengan alamat website http://kebidanan.unsika.ac.id/, ketika menuju link FIKES maka akan masuk ke prodi Kebidanan dan tidak menemukan website fakultas. Tampilan yang rapi dan minimalis. Tidak terdapat informasi yang update berupa agenda perkuliahan, presetasi mahasiswa dan dosen serta acara-acara fakultas. Fakultas Teknik dngan alamat website www.ft.unsika.ac.id tidak dapat diakses samasekali. Sedangkan Pascasarjana tidak memiliki websitenya sendiri.

b. Analisis Isi Website Unsika

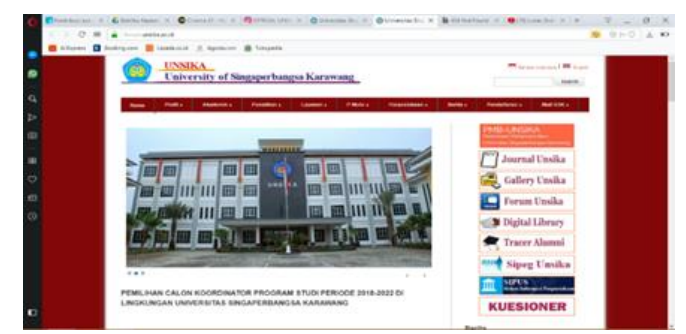

Gambar 3. Tampilan pada website Unsika

Sumber gambar : www.unsika.ac.id

Pada halaman website unsika.ac.id, ada berbagai menu yang ditampilkan yang memuat informasi tentang unsika. Dalam website unsika informasi yang di unggah oleh admin unsika tidak menyantumkan tanggal pengunggahan, jadi tidak tersedia informasi tersebut kapan di unggah. Dalam gambar 3 tampak gambar dalan headline tampilan website unsika.ac.id merupakan foto lama terlihat dari logo unsika pada gedung masih menggunakan logo lama. Ada beberapa menu yang tidak dapat digunakan seperti menu mail unsika, tracer alumni, forum unsika, digital library. Selain itu ada beberapa gambar didalam konten yang tidak dapat dimuat, beberapa konten yang tidak update atau masih memuat informasi lama yang seharusnya sudah dapat diperbaharui seperti pada menu profile pada sub menu sambutan rector, selain itu menu Akademik di website unsika.ac.id di sub menu peraturan akademik tidak update dan kosong tidak ada konten apapun, sama halnya pada menu penelitian di sub menu kebijakan tidak memuat informasi apapun. Pada menu profil di website unsika.ac.id, di sub menu beasiswa semua bagian dapat dilihat dan tidak terjadi masalah hanya saja tidak dicantumkan kapan terlaksananya beasiswa tersebut dan tanggal sehingga mahasiswa kurang mendapatkan informasi 
dengan akurat. Pada menu Akademik di website unsika.ac.id, di sub menu akreditasi memuat informasi tetapi tidak update informasi terbaru, bisa dilihat informasi mengenai prodi ilmu komunikasi tertulis masa berlaku 20 juli 2018 sedangkan pada prodi ilmu komunikasi sudah melaksanakan re-akreditasi dan berperingkat B. Pada menu Pendaftaran di website unsika.ac.id, sub menu di dalam menu Pendaftaran dapat dilihat dan tidak terjadi masalah. Dalam sub menu ini, Pendaftaran Mahasiswa Baru (PMB) akan di alihkan ke website pmb.unsika.ac.id dimana website itu merupakan halam resmi dari Pendaftaran Mahasiswa Baru (PMB). Tetapi, belum diketahui juga lebih lanjut informasi yang di unggah pada sub menu Pendaftaran Mahasiswa Baru (PMB) ini merupakan unggahan terbaru atau tidak, karena tidak ada tanggal pengunggahan yang tersedia di website pmb.unsika.ac.id

\section{Media Sosial Universitas Singaperbangsa Karawang}

\section{a. Facebook Universitas Singaperbangsa Karawang}

Facebook adalah sebuah web jejaring sosial yang didirikan oleh Mark Zuckerberg dan diluncurkan pada 4 Februari 2004 yang memungkinkan para pengguna dapat menambahkan profil dengan foto, kontak, ataupun informasi personil lainnya dan dapat bergabung dalam

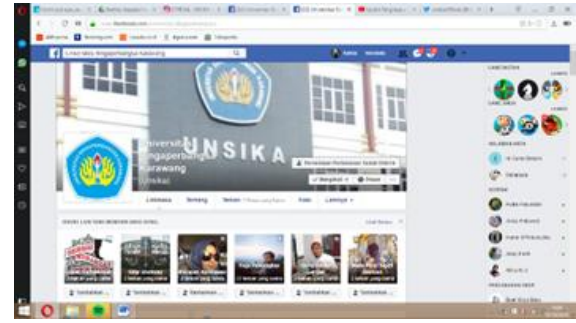

komunitas untuk melakukan koneksi dan berinteraksi dengan pengguna lainnya.

Gambar 4. Tampilan halaman facebook resmi milik Unsika

Sumber gambar : www.facebook.com/Unsika

Pada gambar 4 adalah tampilan halaman facebook yang merupakan akun resmi media sosial facebook milik unsika. Jenis akun ini merupakan akun pribadi bukan jenis akun halaman pada facebook. Postingan pertama diunggah pada tanggal 4 oktober 2018 dan postingan terakhir diunggah pada tanggal 10 oktober 2018.

\section{b. Twitter Universitas Singaperbangsa Karawang}

Twitter adalah sebuah media sosial yang menyebarkan informasi pesan secara singkat, padat dan real time di dalam kalimat kurang dari 140 karakter kepada pembacanya diseluruh dunia. @Unsikainfo merupakan akun resmi Unsika pada sosial media Twitter, hal ini diketahui berdasarkan info profil pada akun facebook humas unsika. Akun twitter ini dibuat pada bulan februari 2017 dan belum menggunggah twit satu pun.

\section{c. Instagram Universitas Singaperbangsa Karawang}

Instagram adalah sebuah aplikasi berbagi foto dan video yang memungkinkan pengguna mengambil foto, mengambil video, menerapkan filter digital, dan membagikannya ke berbagai layanan jejaring sosial, termasuk milik Instagram sendiri. @Official.unsika merupakan akum media sosial instagram yang dimiliki oleh UNSIKA. Akun ini di kelola bagian humas unsika, hal ini diketahui berdasarkan info profil pada akun facebook humas unsika. Pada akun media sosial instagram @official.unsika yang diakses pada tanggal 15 oktober 2018 terdapat 30 kiriman yang berisi informasi civitas unsika, unggahan pertama diunggah pada tanggal 19 juli 2017 dan terakhir diunggah pada tanggal 10 oktober 2018. Selain itu akun ini memiliki 1.165 pengikut dan 43 diikuti. Pada akun Instagram @Officialunsika jarak waktu konten unggahan terbaru dengan konten unggahan sebelumnya adalah 33 hari. Konten unggahan terbaru diunggah pada tanggal 
10 oktober 2018 yang berisi enam konten dan konten unggahan sebelumnya diunggah pada tanggal 7 september 2018 yang berisi satu konten. Banyak postingan yang tidak memiliki keterangan gambar secara jelas dan detail sehingga informasi yang diberikan tidak lengkap.

\section{d. Youtube Universitas Singaperbangsa Karawang}

YouTube adalah sebuah situs web video sharing (berbagi video) populer dimana para pengguna dapat memuat, menonton, dan berbagi klip video secara gratis. Umumnya video-video di YouTube adalah klip musik (video klip), film, TV, serta video buatan para penggunanya sendiri. Format yang digunakan video-video di YouTube adalah .flv yang dapat diputar di penjelajah web yang memiliki plugin FlashPlayer Unsika memiliki akun resmi sosial media di youtube. Akun youtube ini hanya memiliki 10 vidio unggahan, unggahan terbaru diunggah 9 bulan yang lalu dari tanggal diakses yaitu 15 Oktober 2018 dan memiliki 139 subscriber. Unggahan pada akun media sosial youtube Unsika ini berisi informasi terkait civitas Unsika. Adapun video yang diposting 9 video tentang SIAKAD online (user manual) satu video tentang SMMPTN 2017.

\section{Kendala Dalam Menjalankan Aktifitas Cyber PR Universitas Singaperbangsa Karawang}

Dengan penggunaan media cyber yang beragam maka bentuk-bentuk aktifitas cyber $P R$ juga menjadi beragam. Berikut ini adalah bentuk-bentuk implementasi cyber $P R$ di UNSIKA yang dapat berkontribusi untuk meningkatkan reputasi beserta kendalanya:

\section{Pembuatan berita (press release)}

Divisi Humas UNSIKA belum terlihat serius dalam melakukan aktifitas cyber $P R$ hal ini dapat dilihat dari minimnya berita yang di publikasikan melalui website dan media sosial sehingga banyak berita berupa prestasi mahasiswa dan dosen, kegiatan atau event, Beasiswa serta kabar terbaru dari unsika yang dilakukan tidak dipublikasikan. Adapun press release yang bisa humas hasilkan dan publikasikan antara lain : 1) Prestasi dosen Seperti Lulus Doktor, Menerima Hibah penelitian dan pengabdian, Menjadi pemakalah atau pembicara di forum ilmiah, menerima penghargaan dari pemerintah, menerima beasiswa, Jurnal tembus scopus dll; 2) Prestasi mahasiswa seperti Lulus Cumlaude, menerima beasiswa, menang lomba, mendapatkan award dari pemerintah, mewakili universitas baik nasional dan internasional, Prestasi UKM dll; 3) Kegiatan dan event seperti wisuda, seminar, workshop, diesnatalis, acara call paper, acara universitas, acara amal, acara kegiatan mahasiswa, Lomba yang diadakan mahasiswa dll.

2. Pembuatan berita video

Kontribusi berita video bagi peningkatan reputasi berasal dari publikasi berita seputar penelitian dan prestasi yang dicapai serta acara yang diselenggarakan namun media cyber unsika tidak memanfaatkan hal tersebut tidak ada video yang dipublikasi melalui akun unsika.official baik di youtube, website, maupun media sosial lainnya. Namun video-video acara atau event di publikasikan oleh komunitas Fotografi dan videografi yaitu@unsika.tm yang anggotanya merupakan mahasiswa dari berbagai prodi.

\section{Penyediaan informasi di situs resmi}

Ketersediaan informasi sebenarnya sangat berguna untuk mendapatkan citra baik khalayak tentang unsika namun Informasi di situs resmi hanya sebatas pengumuman saja tidak ada berita atau press release yang dapat meningkatkan citra unsika seperti prestasi dosen dan mahasiswa, kegiatan mahasiswa ataupun event yang dibuat dosen dan mahasiswa. Padahal banyak sekali press release yang dapat dihasilkan oleh humas mengingat unsika banyak memiliki prestasi dan kegiatan baik akademik maupun non akademik. Analisis Aktifitas cyber PR melibatkan interaksi dan penyebaran pesan. Cutlip dkk (2009: 408) menawarkan 7C sebagai aspek-aspek yang dapat digunakan agar interaksi dan penyebaran pesan berjalan dengan baik yaitu: 1) Credibility (Kredibilitas), untuk Kredibilitas seharus dalam setiap pesan yang diberikan, Divisi Humas 
Unsika harus selalu menyertakan tokoh dengan latar belakang pendidikan yang tinggi, diantaranya bergelar magister, doktor hingga profesor. Dengan demikian masyarakat akan lebih percaya terhadap isi berita namun kenyataannya melalui website resmi unsika yang beralamat www.unsika.ac.id tidak ada press release setiap kegiatan yang ditampilkan hanya pengumuman untuk internal saja; 2) Context (Konteks), dengan latar belakang UNSIKA sebagai institusi pendidikan maka seharusnya informasi yang diberikan baik melalui press release, berita video dan interaksi mempunyai kaitan dengan keilmuan dan penelitian namun hal ini tidak dilakukan pihak Humas sehingga tidak dapat di analisis dengan baik; 3) Content (isi), faktor ini dapat dilihat dari isi pesan di press release dan interaksi di media sosial. Isi pesan yang disebarkan oleh humas UNSIKA kurang dapat menjawab kebutuhan masyarakat karena banyak prestasi dan kegiatan dosen dan mahasiswa untuk masyarakat yang sangat kurang di publikasikan. Kebanyakan isi pesan masih bersifat internal dan kurang maksimal; 4) Clarity (Kejelasan), untuk menciptakan persamaan makna maka bahasa yang digunakan pada setiap bentuk cyber $P R$ oleh Humas Unsika adalah bahasa Indonesia yang sederhana sehingga dapat mudah dimengerti oleh masyarakat; 5) Continuity and consistency (Kontinuitas dan konsistensi), divisi Humas UNSIKA masih belum konsisten menghasilkan press release, berita video sesuai dengan informasi terbaru yang didapatkan; 6) Channel (Saluran) untuk menyebarkan pesan dan berinteraksi dengan masyarakat, Humas UNSIKA menggunakan media yang banyak diakses oleh masyarakat yaitu situs resmi dan media sosial seperti Instagram, facebook dan youtube; 7) Capability of the audience (Kemampuan khalayak), masih banyak khayalak yang kurang puas terhadap informasi yang dipublikasikan melalui media cyber UNSIKA hal ini dikarenakan informasi yang di publikasikan masih bersifat internal, sehingga khalayak masyarakat dan mahasiswa bingung jika ingin mencari informasi yang mereka inginkan.

Berdasarkan data yang didapat dari hasil penelitian, tidak hanya 7C yang dapat ditemui pada aktifitas cyber PR oleh Humas UNSIKA. Didapati peneliti bahwa ada satu faktor yang dapat ditambahkan karena kelebihan yang ditawarkan oleh media online yaitu connectivity (konektivitas). Konektivitas yang dibangun oleh Humas UNSIKA adalah menghubungkan kolom komentar di laman pemuatan press release dan informasi dengan facebook. Dengan demikian maka sebenarnya pembaca dapat dengan mudah berkomentar selama terhubung dengan facebook. Seharusnya konektivitas juga dapat dilihat dari penyebaran press release /informasi secara otomatis di Instagram, facebook dan twitter bersamaan dengan waktu press release tersebut dimuat di situs resmi UNSIKA. Namun Humas UNSIKA tidak memberikan respon yang baik serta lama jika pembaca ingin bertanya. Pembuatan press release, berita video dan penyediaan informasi seharusnya dilakukan secara maksimal namun humas UNSIKA belum terlalu konsisten dala membangun cyber $P R$.

Dowling (2006), ada tiga peran utama dari $P R$ yang dapat digunakan untuk meningkatkan reputasi organisasi. Tiga peran tersebut dapat dijalankan dengan menggunakan media online yaitu: 1) Komunikasi eksternal secara langsung yang didesain untuk meningkatkan kesadaran dan pemahaman serta apresiasi dari publik utama. Aktivitas komunikasi eksternal Divisi Humas UNSIKA secara tidak konsisten dilakukan melalui media online dan tidak memperbaharui informasi tentang UNSIKA kepada masyarakat. Padahal banyak Informasi tersebut dapat berkaitan dengan prestasi-prestasi dan upaya-upaya UNSIKA yang sejalan demi meningkatkan reputasi sebagai universitas negeri baru; 2) Mempertahankan atau menjelaskan tentang aksi perusahaan. Dalam menjalankan peran ini, Humas UNSIKA menggunakan media sosial. untuk mempertahankan dan menjelaskan aksi UNSIKA namun penggunaan media sosial hanya memuat pengumuman internal saja dan tidak maksimal; 3) Komunikasi internal tentang perusahaan sehingga karyawan akan merasa menjadi bagian dari perusahaan. Humas harusnya terus mengabarkan tentang situasi terkini UNSIKA melalui grupgrup facebook internal atau 
melalui publikasi di media online sebagai bagian dari komunikasi internal, namun hal ini masih minim dilakukan pihak HUMAS UNSIKA.

Hal ini seharusnya tidak akan terjadi jika ada evaluasi yang dilakukan oleh Humas UNSIKA. Evaluasi menurut Cutlip dkk (2009:319) berfungsi untuk menciptakan kesesuaian termasuk didalamnya kesesuaian dalam tahap aktifitas program $P R$. Melalui evaluasi, Humas UNSIKA dapat menemukan penyebab dari ketidaksesuaian tersebut dan kemudian menemukan solusinya.

\section{Analisis Strategi Cyber PR UNSIKA dalam Publikasi Informasi}

Publikasi informasi yang dilakukan pihak Humas sangat statis sekali disini humas hanya menunggu informasi saja padahal seorang humas harus aktif mencari informasi yang akan di publikasikan.

"Jika mahasiswa atau civitas ingin memberikan informasi untuk di post ke website maka harus memberikan surat ke kami terlebih dahulu atau ke biro umum, lalu kita dispo ke pimpinan kita, kalau disposisinya "tolong sebarkan ke website" maka oleh staff akan langsung di posting ke website. Tapi kalo informasi yang berasal dari lingkungan rektorat seperti informasi bidang akademik itu langsung kami posting" (hasil wawancara Staff Humas Unsika)

Proses publikasi diatas menurut peneliti kurang relevan dalam kegiatan cyber $P R$ yang harus cepat dan update. informasi yang dihasilkan biasanya sangat dekat antara jarak publikasi dan pelaksanaan kegiatan. Hal ini hendaknya $P R$ dapat merumuskan strategi $P R$ yang baik. Berita berupa Press Release baik berupa kegiatan mahasiswa dan dosen atau pun prestasi tidak pernah terlihat diwebsite hal ini dikarenakan pihak humas hanya meneruskan informasi dari berita yang masuk dan tidak pernah memproduksi berita ataupun informasi sendiri. Adapun informasi yang diteruskan di website merupakan pengumuman yang dibuat pelaksana kegiatan dan humas hanya upload dokumen tersebut dan bersifat internal.

"dari luar seperti ormawa kampus. Dalam Sebenarnya kita tidak punya target untuk memberikan informasi, jadi berapapun data/berita yang masuk akan dipublish jika sudah melalui ijin pimpinan. Dari kami tidak membuat konten tersendiri untuk memberikan informasi, kami hanya mempublish kegiatan - kegiatan internal seperti kegiatan rektorat, fakultas dan kegiatan sehari biasanya tidak ada berita, paling kalau seminggu maksimal 5 berita yang masuk ke kami.” (Wawancara Staf Humas Unsika)

\section{KESIMPULAN DAN SARAN KESIMPULAN}

1. $\quad P R$ merupakan bagian penting dalam perusahaan selain fungsinya sebagai penghubung antara perusahaan dengan para stakeholders (publik), juga berfungi untuk membangun image positif agar tercipta trust (kepercayaan) publik terhadap Perusahaan. Dalam membangun citra institusi, Unsika menggunakan website dan media sosial antara lain Facebook, Twitter, Instagram dan Youtube sebagai media cyber $P R$ yang membutuhkan manajemen yang baik mulai dari menganalisis situasi komunikasi, merumuskan tujuan, Menentukan publik serta personel yang terlibat, menentukan media yang digunakan, menentukan anggaran, merencanakan program, serta analisis hasil akhir. Penggunaan website dan media sosial adalah langkah tepat dalam membangun citra positif karena maraknya pengguna media sosial di Indonesia. Namun kurang maksimalnya aktifitas cyber $P R$ Unsika membuat Isntitusi ini cukup sulit bersaing di media internet. 
2. Kendala proses cyber public relations dalam meningkatkan citra positif Unsika terletak pada sumber daya manusianya, kurangnya pemanfaatan media informasi yang sudah ada serta proses publikasi yang dinilai kurang relevan sehingga kegiatan cyber $P R$ kurang cepat dan update.

3. Strategi public relations menghadapi tantangan dalam persaingan cyber public relations adalah dengan meningkatkan kualitas humas, memperbaiki proses publikasi yang stasis menjadi dinamis, humas harus lebih intens dalam memproduksi informasi dan memaksimalkan pemanfaatan fungsi media cyber $P R$ seperti website dan media sosial.

\section{SARAN}

Dalam proses peningkatan reputasi Unsika dari salah satu perguruan tinggi negeri baru di Indonesia banyak upaya yang harus dilakukan oleh berbagai pihak. Salah satu upaya yang dilakukan adalah melalui cyber $P R$. cyber $P R$ yang dilakukan oleh Humas Unsika harusnya turut berkontribusi dalam hal publikasi. Namun Publikasi yang dihasilkan tidak dapat meningkatkan citra institusi dikarenakan hanya bersifat internal akademik saja padahal banyak prestasi dan kegiatan dosen, mahasiswa serta civitas Unsika yang dapat meningkatkan citra institusi melalui publikasi tersebut. Selain itu, sebagai humas harus lebih aktif dan kretif lagi contohnya pada website hanya mengupdate berita internal saja dan desain yang standar serta dengan waktu yang berdekatan.

\section{Ucapan Terima kasih}

Penulis mengucapkan terima kasih kepada berbagai pihak khususnya para partisipan penelitian yang telah membantu dalam penelitian yang hingga penyelesaian penulisan karya ilmiah ini.

\section{REFERENSI}

Ardianto, E.( 2009). Public relations praktis. Bandung: Widya Padjajaran,

Aspikom. (2011). Komunikasi 2.0 teoritisasi dan implikasi. Yogyakarta:Buku Litera

Breakenridge, D. K. (2008). PR 2.0: new media, new tools, new audiences. New Jersey: FT Press,

Butterick, K (2012). Pengantar Public Relations: Teori dan Praktik. Rajawali Pers, Jakarta.

Cutlip, S. M., Allen H. C., \& Glen M. B. (2009). Effective public relations (9 ed). .....Prentice Hall

Fajar, W. (2011). Komunikasi Al-Qur'an Perspektif dakwah integral. Yogyakarta

Julius, B.O. (2001). Cyber public relations. Jakarta Elexmedia,

Morissan. (2008). Manajemen public relations. Jakarta: Prenada

Ngurah, I G.(1999). Manajemen hubungan masyarakat. Yogyakarta: Penerbitan Universitas Atmajaya Yogyakarta,

Pawito, (2007). Penelitian komunikasi kualitatif.Yogyakarta: LKIS

Ruslan, R.(1995). Praktik dan solusi public relations dalam situasi pemulihan citra. Jakarta: Ghalia Indonesia,.

Ruslan, R.(2007). Manajemen public relations \& media komunikasi. Jakarta: Raja Grafindo Persada Jakarta.

Zarella, D.( 2011). The social media marketing book. Jakarta: PT Serambi Ilmu 